\title{
Analysis of Accounting Learning Quality and College Students' Financial Literacy
}

\section{Tri Kurniawati}

Universitas Negeri Padang, Padang, Indonesia, $\bowtie$ (e-mail) trifeunp@gmail.com

\begin{abstract}
One of the ultimate goals of all university education programs is to enhance the economic and financial literacy of our citizenry. This is the strategic issues in rebalancing the economic agenda. This study aims to analyze: a) the quality of accounting learning process, students achievement and the level of financial literacy of accounting students in Universitas Negeri Padang (UNP), b) the influence of the learning quality on the students achievement in Universitas Negeri Padang, and c) the influence of the learning quality and students achievement on the financial literacy of accounting students in Universitas Negeri Padang. This studyusesa quantitativeresearchapproach by using path analysis. The samples are consisting of 227 accounting students. The research results show that the quality ofthe learningprocess have positive and significanteffecton student achievement. But,the quality ofthe learningprocess and students achievement do not significantly influence the financial literacy of accounting students in Universitas Negeri Padang.
\end{abstract}

Keywords: learning quality, financial literacy, student achievement.

\section{Introduction}

The Indonesian economy has been continuously dealing with a crisis. In the last two decades, a series of economic and financial crisis hit the national economy and affect various aspects of life. As a result, the accelerated development that has been done so far shows a decreasing graphic. Although the crisis is not only experienced by Indonesia but also many other countries and even developed countries as well, the national economic development should still be built under a solid foundation.

The historical records have shown that the economic crisis on 1997 and 2008 provide an illustration on the importance of maintaining financial system stability. This should be coupled with efforts to mitigate the potential for failure in financial stability. According to Hamid (2012), in the economic crisis of 1997, bank liquidations, that are assessed as an attempt to save the banks from systemic failures, proved to have unexpected psychological effects. Further efforts to overcome this actually impacted on the losses of hundreds of trillions of rupiah that cannot be withdrawn and accounted for until now. Similar conditions were also experienced in the 2008 financial crisis, especially in Bank Century case. Based on the APEC Finance Deputies 2011 meeting, it was also explained that the crisis phenomenon that began in 2007 resulted in the highest unemployment rate increase in history. The risks of increasing unemployment rate are still experienced by most of developed countries, while the risk of overheating is experienced by most of developing countries because the hot money flow goes into its economy (Pacific, 2011).

There are various policies that can be taken to get out of the crisis or to mitigate the crisis. These policies can be in macro or micro economic context, and in the long term and short term handling. One of the strategic issues raised in APEC Finance Deputies in 2011 is to include financial inclusion to rebalance the economic agenda. Financial inclusion is an activity to reduce barriers for poor people to use financial services. Discussion of financial inclusion does not mean to go through the bank, but also through non-formal institutions such as cooperatives and local credit institutions. There are five financial inclusion pillars of financial education, namely, financial eligibility, supportive regulation, intermediate facilitating and distributions. The quality of financial inclusion, on the other hand, can be seen from two aspects: financial literacy and level of consumer protection (Pacific, 2011). 
The crisis will deeply impact on society if the people do not have an adequate understanding of the financial system. Every time there is a decline in economic conditions or inflation and even a crisis, people tend to be forced to accept and suffer losses, not to mention the life habits of the people that tend to be wasteful and consumptive. Investments are also low because of their lack of access to money markets and capital markets. Financial education becomes a serious challenge in Indonesia. Financial education is still very low both at primary, secondary and even higher education level; therefore, it will be important to implement financial education as it will be useful in making financial plans in the future to achieve economic prosperity.

In order to respond to this great challenge, the participation of educational institutions in providing financial education for the community or the students is needed. According to previous research, the best way to improve adult behavior is to teach good behavior since childhood, including by teaching financial behavior (Mandell, 2012; Xiao, Shim, Barber, \& Lyons, 2007).

There are various factors that affect financial literacy, both from internal factors and external factors. These factors include demographic factors (Beal \&Delpachitra, 2003; Chen \& Volpe, 1998; Worthington, 2006), socioeconomic factors (Worthington, 2006) financial experience, financial education (Mandell, 2012; Peng, Bartholomae, Fox, \&Cravener , 2007), economic conditions (Worthington, 2006) and family characteristics (Mandell, 2012; Mitchell, 2009). Out of these various factors, the financial education becomes one of the important one, especially in universities. If universities want to participate in building the community's financial literacy, they should develop the financial education.

Grimes, Rogers, \& Smith, (2010) argue that "the ultimate goal of all high school economic education programs is to enhance the economic and financial literacy of our citizenry". Therefore, the process of education, especially economic learning, should not only be oriented on the achievement of students achievement or cumulative achievement index (GPA) but also on the formation of financial and economic skills or financial and economic literacy. Nidar and Bestari (2012) state that from various studies on students' financial literacy, it was found that the knowledge of college students on finance is low and is even lower in the level of financial literacy. The main problem that may cause this kind of condition is the financial learning process that has not been oriented on the development of financial literacy. The focus of education in universities is still on achieving academic achievement or on an improvement of student grades.

Grimes, Rogers, \& Smith, (2010) support this statement and explain that the effectiveness of the learning process has been more focused on measuring the learning achievement of learners. Although such methods tend to be generally accepted as a tool for assessing learning programs, such conventional approaches tend to override long-term effects on how students can apply their student's achievement in real life after completing their educational program. Allgood, Lincoln, \& Bosshardt (2004) further describe that a more comprehensive assessment process should include an assessment of the extent to which students are able to apply their economics knowledge in real life for the long term. A study by Nidar and Bestari (2012) on Padjadjaran University students with a sample of 400 students found that the level of financial literacy of the students is still in the low category. On the other hand, the results are quite surprising; the GPA, students' participation in lectures of financial management, knowledge of financial management obtained from formal education at universities and participation in seminars and training on financial management have no significant effect on the students' financial literacy.

Based on the above explanation, it is still interesting to continue research on financial literacy, both in terms of its inclusion and relation to the learning quality (both in terms of process and students achievement). Therefore, this study aims to analyze: a) the quality of accounting learning process, students achievement and the level of financial literacy of accounting students in Universitas Negeri Padang, b) the influence of the learning quality on the students achievement in Universitas Negeri 
Padang, and c) the influence of the learning quality and students achievement on the financial literacy of accounting students in Universitas Negeri Padang.

\section{Methods}

This research will be conducted at the Faculty of Economics Universitas Negeri Padang, West Sumatera province, Indonesia. The population in this study is all students of Accounting in the Faculty of Economics Universitas Negeri Padang. The students consist of students of accounting courses and students of Economics Education courses with accounting skills. The population of this study is 530 people. The determination of the number of samples is done by using the Slovin formula with error $5 \%$. The sample size is 227 people.

The data collection on students' financial literacy was done by using the Financial Literacy Test issued by National Financial Educators Council. The data collection of students'achievement was in the form of documentation study of students' transcript which is stated in the form of cumulative achievement index (GPA). The data collection of the learning quality process was done by using a questionnaire. This study used SEEQ (Students' Evaluation of Educational Quality) developed by Marsh et. al.

To test the research hypothesis, the path analysis was employed. Prior to the path analysis, the pre-paid analysis test was done in the form of normality test and homogeneity test. Furthermore, the analysis of paths was done in two sub-structures.

Research will be conducted at the Faculty of Economics UNP. The population in this study is all students accounting expertise in the Faculty of Economics UNP. The students consist of students of accounting courses and students of economics education courses with accounting expertise. The population of this study is 530 people. Determination of the number of samples is done by Slovin formula with error $5 \%$. The sample size is 227 people.

Collecting data on student financial literacy is done by the test that is Financial Literacy Test issued by National Financial Educators Council. The data collection of student student's achievement is done by documentation study through student study result report stated in the form of cumulative achievement index. Data collection on the learning quality process will be done by questionnaire. In this study used SEEQ (Students' Evaluation of Educational Quality) developed by Marsh et. al. To test this research hypothesis used path analysis. Prior to the path analysis, the pre-paid analysis test was done in the form of normality test and homogeneity test. Furthermore, the analysis of paths with two sub-structures.

\section{Results and Discussions}

The variables of this study consist of the quality of the learning process, students achievement and student financial literacy. Based on the data processing, the descriptive analysis of these research variables can be seen in the table below.

Table 1Descriptive Variable Analysis Results

\begin{tabular}{clcccc}
\hline No & \multicolumn{1}{c}{ Variable } & Mean & $\begin{array}{c}\text { Std. } \\
\text { Deviation }\end{array}$ & TCR (\%) & Note \\
\hline 1 & $\begin{array}{l}\text { Learning Quality } \\
(\mathrm{X} 1)\end{array}$ & 4,87 & 0,81 & 81 & Very Good \\
\hline 2 & $\begin{array}{l}\text { Student } \\
\text { Achievement (X2) }\end{array}$ & 3,06 & 0,44 & - & Good \\
\hline 3 & $\begin{array}{l}\text { Financial Literacy } \\
(\mathrm{Y})\end{array}$ & 37,93 & 9,48 & - & Low \\
\hline
\end{tabular}


Based on Table 2 above, it can be seen that the quality of the learning process is fairly high with an average of 4.87 and a maximum score of 6 . The level of respondent's achievement is $81 \%$ or included as very good. The results of this analysis describe that the learning process implemented in Faculty of Economics Universitas Negeri Padang to Accounting students both for Economic Education Study Program and Accounting Study Program is categorized as good. The average GPA of Accounting students of Faculty of Economics Universitas Negeri Padang is 3.06 or categorized as good, with the standard deviation of 0.44 . The level of financial literacy of the students scored an average of 37.93 with a standard deviation of 9.48 and a maximum score of 100 if all test items can be answered correctly. This means that the students are only able to get an average score of 37.93 or are only able to answer $37.93 \%$ of the test or 11 items correctly out of a total of 30 items of questions on the test. This result shows that the level of financial literacy of Faculty of Economics Universitas Negeri Padang students is low. The level of financial literacy of Accounting students only achieved an average of 37, 93 or classified as low in a maximum value of 100 .

To test the hypothesis that has been proposed in this research, the path analysis was used. Prior to testing the path analysis, prerequisite tests in the form of normality and heteroscedasticity tests were performed. The normality testing was performed by using non-parametric Kolmogorov-Smirnov test with a value of $\alpha 0.05$. Based on the results of Kolmogorov-Smirnov test, the obtained significance value for the residuals of both sub-structures is respectively 0.232 and 0.682 or larger than $\alpha 0.05$. This means that both residuals are normally distributed. The heteroscedasticity test was done by using the Glejser test. The results show that noheteroscedasticityproblem was found in this study.

\section{Block I (Sub Structure 1):}

The first hypothesis in this study is that the learning quality process $(\mathrm{X} 1)$ has a positive and significant effect on the student's achievement (X2) of accounting students of Faculty of Economics Universitas Negeri Padang.

From the test results, it can be seen that for the level of significance of this research with $\alpha 0.05$, the obtained probability value is Sig $<0.05$ which is 0.044 , which also means that the test results are significant. The path coefficient of the influence of the learning process quality variable on the learning outcome is equal to $0,134\left({ }_{X 2 X 1}\right)$. This suggests that the relationship between the quality of the learning process and the student's achievement is positive and significant. The extent of the influence of the academic service quality variable on the learning outcome is shown by the R Square value of 0,018 or $1,8 \%$. The residual coefficient $\left({ }_{X 2 \varepsilon 1}\right)$ can be calculated as follows:

$$
P_{x 2 \varepsilon 1}=\sqrt{1-R^{2}}=\sqrt{1-0,018}=0,99
$$

The empirical model of the relationship between $\mathrm{X} 1$ and $\mathrm{X} 2$ can be mathematically expressed as follows:

$$
X 2=0,134 X 1+0,99 \varepsilon 1
$$

In which:

$\varepsilon=$ residual.

$\mathrm{X} 1$ = Learning quality process

$\mathrm{X} 2=$ Students achievement 


\section{Block Line 2 (Sub Structure 2):}

The second hypothesis in this study is the quality of the learning process (X1) and student's achievement $(\mathrm{X} 2)$ has a positive and significant impact on the financial literacy $(\mathrm{Y})$ of students of the Faculty of Economics Universitas Negeri Padang.

From the test results, it can be seen that for the significance level of this research with $(\alpha) 0.05$, the obtained probability value isSig $>0,05$ for the variable $\mathrm{X} 1$ and also $\mathrm{X} 2$, which is 0,058 and 0,961 respectively, which also means that the test result is not significant. The path coefficient of the influence of $\mathrm{X} 1$ on $\mathrm{Y}$ is 0.127 .

The effect of $\mathrm{X} 1$ and $\mathrm{X} 2$ on $\mathrm{Y}$ is shown by the adjusted $\mathrm{R}$ Square of 0.016 or only $1.6 \%$. The rest $98.4 \%$ is influenced by other factors. Hence, the value of residual coefficient () can be calculated as follows:

$$
P_{Y \varepsilon 2}=\sqrt{1-R^{2}}=\sqrt{1-0,016}=0,99
$$

The empirical model of the relationship between $\mathrm{X} 1$ and $\mathrm{X} 2$ can be mathematically expressed as follows:

$$
Y=0,127 X 1+0,003 X 2+0,99 \varepsilon 2
$$

In which:

$\varepsilon=$ residual.

$\mathrm{X} 1$ = Learning quality process

$\mathrm{X} 2$ = Students achievement

$\mathrm{Y}=$ Financial Literacy

From the results of sub-structures 1 and 2, the overall analysis result of this research model is as follows:

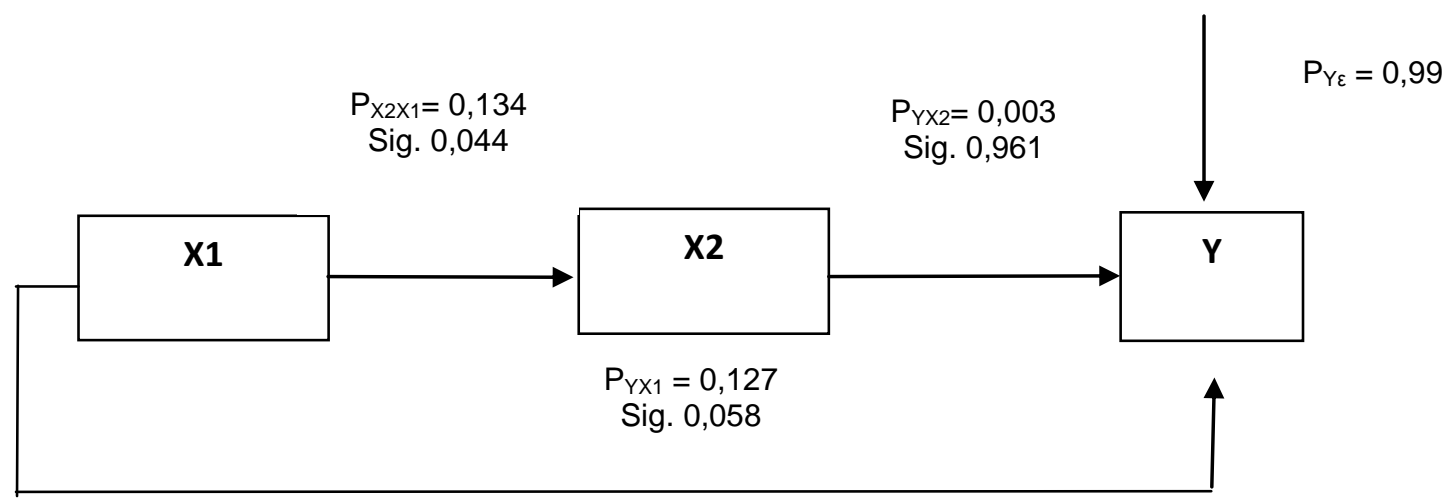

The direct and indirect effects between the variables of this study can be seen in Table 5 below. The direct effect is shown on the path coefficient, while the indirect effect is the influence mediated by the intervening variable (in this case variable $\mathrm{X} 2$ ) obtained by multiplying the path coefficient, namely Px2x1 multiplied by Pyx2.

The results of this study have shown that the quality of the learning process has no significant effect on the financial literacy of the students either directly or indirectly through the learning outcome variable. However, the quality of the learning process has a positive and significant impact on student's achievement. 
Table 2 Conclusion of Path Analysis Result

\begin{tabular}{lllll}
\hline Variable Effect & Direct & $\begin{array}{c}\text { Indirectly } \\
\text { through } \mathrm{X} 2\end{array}$ & Total & Note \\
\hline $\mathrm{X} 1$ on $\mathrm{Y}$ & 0,127 & & 0,127 & Insignificant \\
\hline $\mathrm{X} 1$ on $\mathrm{X} 2$ & 0,134 & - & 0,134 & Significant \\
\hline $\mathrm{X} 2$ on $\mathrm{Y}$ & 0,003 & - & 0,003 & Insignificant \\
\hline $\mathrm{X} 1$ on $\mathrm{Y}$ & - & 0,000132 & 0,0001 & \\
& & & 32 &
\end{tabular}

Source: Research Data Analysis 2014

Based on this result, this study provides the empirical evidence that the quality of the learning process will be able to improve student student's achievement. The higher the quality of the learning process held by lecturers, the ability and students achievement achieved by students will also increase.

The findings of this study are supported by what the Center for High Impact Philanthropy (Hightower, Lloyd, \& Swanson, 2011) suggests that "a quality teacher is a master of the mastery, command of a broad set of pedagogic skills, and communications / interpersonal skills. Quality teachers are lifelong learners in their subject areas, teach with commitment, and are reflective upon their teaching practice. They transfer knowledge of their subject matter and the learning process through good communication, diagnostic skills, understanding of different learning styles and cultural influences, knowledge about child development, and the ability to marshal a broad array of techniques to meet student needs. They set high expectations and support students in achieving them. They establish an environment conducive to learning, and leverage available resources as well as inside the classroom." Similarly, the results of studies by Greenwald, Hedges, \& Laine (1996) and Harris (2007) found that teacher quality (ability, education and teacher experience) had a positive and significant impact on student student's achievement.

Unfortunately, the quality of the learning process and students achievement do not have a significant influence on the financial literacy level of Accounting students of Faculty of Economics Universitas Negeri Padang. Although the learning quality is considered very good by the students, their financial literacy level is still low. Similarly, high GPA achievements do not differ significantly in their ability to achieve high levels of financial literacy, and despite the students' GPA that is dispersed from low to very high, the overall the financial literacy value is relatively low. Students' knowledge about financial planning, investment, insurance, credit and also financial risk is still relatively minimal. This is on the contrary to Grimes's (2010) opinion that the ultimate goal of all high school economic education programs is to enhance the economic and financial literacy of our citizenry. Thus, the process of education, especially economic learning, should not only be oriented on the achievement of student's achievement or cumulative achievement index (GPA) but also on the formation of financial and economic skills or financial and economic literacy.

The results of this study, however, support the previous findings. The study conducted by Nidar and Bestari (2012) on students at Padjadjaran University showed that the financial literacy score of the students reached an average of $42.1 \%$ or included in the low category. In this study, the students' GPA and knowledge of financial management that they receive from lectures also have no significant effect on their financial literacy. This might be related to findings by Grimes, Rogers, \& Smith (2010) that the effectiveness of the learning process has been focused on measuring the student's achievement of learners. Although such methods tend to be generally accepted as a tool for assessing learning programs, such conventional approaches tend to override long-term effects on how participants can apply their student's achievement in real life after completing education. Allgood, 
Lincoln, and Bosshardt (2004) describe that a more comprehensive assessment process should include an assessment of the extent to which learners are able to apply the economic education they acquire in the long term after they finish college.

Various experts and studies have explained the importance of financial literacy to face the development of the modern economy. This problem has also become a prominent topic in the APEC Finance Deputies in 2011 in which various countries, including the developed countries, have begun to give special attention to the level of financial literacy of its people. Financial literacy is currently one of the global priorities (OECD, INFE, 2012). In fact, the Australian government launched the 2011 National Financial Literacy Strategy (NFLS) program which appointed financial literacy as an important core curriculum taught to all students in Australia. Financial literacy is even integrated into subjects such as mathematics, science, history, English as well as various social and humanities knowledge (Blue et al., 2014).

Korea has also implemented a similar policy. With the emergence of financial literacy issues, the Korean government began to revise their economic curriculum by integrating finance into high schools in 2009 and a standardized curriculum for personal finance in 2010 (Jang et al., 2013).

The results of this study and also previous studies are not much different. Studies on financial literacy towards students of Padjadjaran University (Nidar\&Bestari, 2012), students of University of Sumatera Utara (Nababan, 2012) students of STIE Musi Palembang (Mendari et al., 2013), students of UPI Bandung (Krishna, Sari, \& Rofaida, 2007) and also in this study showed a low average score. Economics and Accounting courses that the students took did not have a significant impact. Thus, there certainly needs to be special attention from many parties regarding the issue of financial literacy that has become an important topic at the global level.

\section{Conclusions}

Based on the results of this research, it is concluded that: a) the quality of accounting learning process in the Economics Education Study Program and Accounting Study Program Faculty of Economics Universitas Negeri Padang is rated as very well by its student's, and the student's GPA also shows an average of 3.06 or in good category. However, the level of financial literacy the students are low with an average score of 37,$93 ; b)$ the quality of the learning process has a positive and significant influence on the students' students achievement in the Faculty of Economics Universitas Negeri Padang; and c) the learning quality process and learning outcome have no significant effect on the financial literacy of Accounting students in the Faculty of Economics Universitas Negeri Padang.

Based on the various aspects of the quality of the learning process being assessed, the lowest aspect found in this research is the aspect of the students' enthusiasm. Thus, it is suggested that members of the Faculty of Economics Universitas Negeri Padang organize the learning process in a more enthusiastic, interesting way with a refreshing humor to create a fun learning atmosphere. The findings of this study show that the students' financial literacy level is low. It is suggested that learning is not only theoretical in concept but is also applicable so that it allows students to practice firsthand what they learn through examples of real financial management in everyday life. To the head of the faculty or study program, it is advisable to begin to include financial literacy as an integral part in the curriculum of economics learning so that students are both economically literate and financially literate. At the level of government policy, the results of several studies have shown that students' financial literacy in Indonesia tends to be low. With the financial literacy as a global issue nowadays, it is recommended that the government begin to accommodate the importance of developing the financial literacy of the Indonesian people and make it one of the important contents to be integrated into the secondary education curriculum, especially in the higher education. 


\section{References}

Allgood, S. A. M., Lincoln, N., \& Bosshardt, W. (2004).What studentsremember and say about collegeeconomicsyears later.

Beal, D. J., \&Delpachitra, S. B. (2003). Financial literacy among Australian University Students. Centre for Australian Financial Institutions (CAFI) at the University of Southern Queensland, 1-15. https://doi.org/10.1111/j.1759-3441.2003.tb00337.x

Chen, H., \& Volpe, R. P. (1998).An analysis of personal financial literacy among college students.Financial Services Review, 7(2), 107-128. https://doi.org/10.1016/S1057-0810(99)80006-7

Greenwald, R., Hedges, L. V., \&Laine, R. D. (1996).The effect of schoolresources on student achievement. Review of Educational Research, 66(3), 361-396. https://doi.org/10.3102/00346543066003361

Grimes, P. W., Rogers, K. E., \& Smith, R. C. (2010).High school economic education and access to financial services.Journal of Consumer Affairs, 44(2), 317-335. https://doi.org/10.1111/j.17456606.2010.01171.x

Harris, D. N. (2007).by, (march).

Hightower, A. M., Lloyd, S. C., \& Swanson, C. B. (2011).Improving student learning by supporting quality teaching: Editorial Projects in Education, Inc., (December), 56.

Mendari, A. S., \&Kewal, S. S. (2013).Tingkat literasikeuangan di kalanganmahasiswa STIE MUSI.jurnaleconomia, 9(2), 130-140.

Nababan, D. (2012). Analisispersonalfinancialliteracydanfinancialbehaviormahasiswa strata I fakultasekonomiUniversitas Sumatera Utara.Jurnal Media InformasiManajemen, 1(1).

Krishna, A. S. S., Sari, M., \&Rofaida, R. (2007).Analisis tingkat literasi keuangan di kalangan mahasiswa dan faktor-faktor yang mempengaruhinya. survey pada mahasiswa Universitas Pendidikan Indonesia (financial literacy level analysis among students and its affecting factors. survey on universitas pend, (November), 1-6.

Mandell, L. (2012). The financial literacy of young american adults. UCLA Anderson School of Management, Fink Center Bulletin, No. 1, (1), 7-8.

Mitchell, O. S. (2009). Financial literacy among the young :, 44(2), 358-380.

Nidar, S. R., \&Bestari, S. (2012). Personal financial literacy among university students (case study at padjadjaran university students ,bandung , indonesia). World Journal of Social Sciences, 2(4), 162171.

Pasifik, K. A. (2011). Tantangan pemulihan krisis di kawasan asia pasifik.

Peng, T. C. M., Bartholomae, S., Fox, J. J., \&Cravener, G. (2007). The impact of personal finance education delivered in high school and college courses. Journal of Family and Economic Issues, 28(2), 265-284. https://doi.org/10.1007/s10834-007-9058-7

Worthington, A. C. (2006). Predicting financial literacy in Australia Predicting financial literacy in Australia.Financial Services Review, 15(1), 59-79.

Xiao, J. J., Shim, S., Barber, B. L., \& Lyons, A. C. (2007). Academic success and well-being of college students: Financial behavior matter. The University of Arizona, (November). 